\title{
Avaliação do potencial clarificante de extratos de sementes de Moringa oleífera Lamark em suco de maçã
}

\section{Resumo}

\author{
Maria Isabel L. Silva, Diana C. N. de Lima (PG) e Flávio L. Schmidt (PQ)
}

A semente de moringa possui polímeros com ação coagulante/floculante que tem sido estudado como forma alternativa para a clarificação de águas residuais e salobras. O comportamento desses polímeros na água é semelhante ao processo de clarificação de suco de maçã. Diante disso, o presente estudo teve o objetivo de aplicar este coagulante natural na clarificação de suco de maçã, melhorando seu aspecto durante a vida de prateleira.

Palavras Chave: finning, suco de maçã, origem vegetal.

\section{Introdução}

A semente de moringa vem sendo estudada como uma alternativa no tratamento de águas residuais em substituição a agentes químicos. Seus polímeros possuem potencial coagulante, que baseia-se na ação de polímeros que desestabilizam partículas coloidais de carga negativa presentes na solução ${ }^{1}$. $\mathrm{Na}$ indústria de alimentos, processos semelhantes são conduzidos em sucos de frutas, por exemplo, suco de maçã. Neste caso, é comum a utilização de enzimas, para reduzir e expor cargas das partículas, e gelatina, para promover floculação e sedimentação das partículas em suspensão ${ }^{2}$. Diante disso, os polímeros da semente de moringa podem ser uma alternativa de origem vegetal e de baixo custo na clarificação de suco de maçã, atendendo a um novo mercado, de consumidores vegetarianos e à tendência por alimentos naturais. $\mathrm{O}$ objetivo deste trabalho foi verificar a eficácia de extratos de semente de Moringa oleífera Lamark na clarificação de suco de maçã.

\section{Resultados e Discussão}

A figura a seguir apresenta os resultados obtidos da análise de transmitância. As amostras com letras iguais não possuem diferença significativa entre si, ao nível de 95\%.

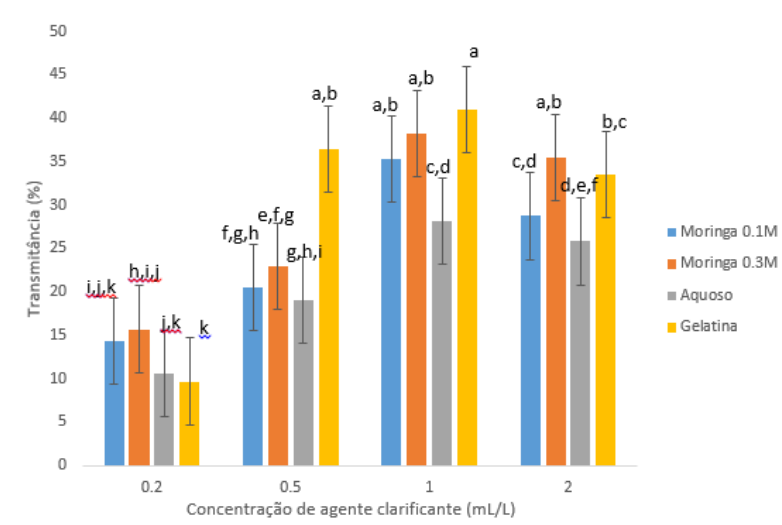

Figura 1. Transmitância de suco de maçã após aplicação de diferentes clarificantes.

As análises físico-químicas realizadas no suco de maçã clarificado e não clarificado não apresentaram diferença significativa.

\section{Conclusões}

A semente de moringa possui potencial como agente de clarificação em suco de maçã. Mais estudos são necessários para desenvolver o potencial dos extratos utilizados.

\section{Agradecimentos}

Agradecimentos a família e amigos que sempre me apoiaram. Agradecimento Especial ao Professor Flávio, a Diana e ao PIBIC/CNPq pela oportunidade.

${ }^{1}$ NDABIGENGESERE, A.; NARASIAH, K. S.; TALBOT, B. G. Active agents and mechanism of coagulation of turbid water using Moringa oleifera. Wat. Res. v. 29, 703-710, 1995.

\footnotetext{
${ }^{2}$ VAN BUREN, J. P.; ROBINSON, W. B. Formation of complex between protein and tannic acid. Journal of Agricultural and Food Chemistry, Easton, v. 17, n. 4, p. 772-777, $1969 .$.
} 